\begin{abstract}
S
Guido Westerwelle

Europe's value. Four propositions concerning Europe's future

The European project is going through the worst crisis of confidence it has ever seen. Many people wonder whether the efforts to tackle the debt crisis will be successful. Political demands which might cause new splits in Europe have been voiced. Old resentments have resurfaced. Fears of a too-mighty Germany are again emerging. This has sown doubts about the European idea as such. This is why the case for Europe needs to be made anew. Therefore, Federal Foreign Minister Guido Westerwelle is presenting propositions on Europe's value. He argues that Europe is indispensable as a player in world affairs, as a community of values and as an economic power. Non-Europe, the turning away from the project of integration, would be a folly. No member state would have more to lose than Germany.
\end{abstract}

\title{
Siegfried Magiera
}

The material and immaterial value of Europe: Treaty basis, political operation and public perception

The author examines the linkage between the material and the immaterial value of European integration since its beginning with the Treaty establishing the European Coal and Steel Community. He comes to the conclusion that the process of integration initially focused on the material value of an economic freedom of movement for market citizens in a common market, although even the ECSC Treaty was already intended to promote immaterial values. With the further development of the integration process the objectives of the treaties were increasingly extended by the immaterial value of a Union citizenship protected by human rights in a constitutional community founded on the values of democracy, the rule of law and solidarity.

\section{Peter-Christian Müller-Graff}

The Area of Freedom, Security and Justice: The Value of Integration for Citizens and Society, Member States and the Union

In order to identify the value of elements of European integration, a yardstick has to be determined at first. Müller-Graff takes as reference points the order of the Basic Law to participate in the development of the European Union bound to certain principles and the corresponding common expectation of the Member States of the Union as laid down in the objectives clause of the Treaty on European Union: promoting peace, its values and the wellbeing of its peoples. On this basis he examines the immaterial value of the so called area of freedom, security and justice. To these ends he assesses the content of this area concept, its contribution to the three overarching objectives of the Union and to coping with present and upcoming challenges (demography, culture and language, civil connections and the building of a polity with solidarity). 


\section{Christian Dreger}

\section{The Economic Value of the European Monetary Union: Benefits from the German Perspective}

The current economic and political crisis management in Europe bears the risk of low real economic growth coupled with higher inflation rates. Unemployment has risen in many member states, causing increasing doubts on the benefits of the monetary union. The article discusses the costs and benefits from a German perspective. The starting point is the macroeconomic development before and after the introduction of the euro area, particularly emphasizing real economic growth and inflation rates. The analysis of the micro- and macroeconomic effects reveals that Germany had disadvantages from the monetary union in the first period, due to inflation below the average. In recent years the advantages have become more visible. This favourable evolution can be attributed, at least in part, to the implementation of labour market reforms.

Ulrike Guérot

\section{The Value of Europe and its Limits: The European Union as Foreign Policy Actor with Deficits}

Particularly the exposure of the European Union to the conflicts in Libya and Syria refers to the fundamental issue of lacking coherence in European Foreign Policy. This lack, moreover, has not been resolved by the institutional innovations in the Treaty of Lisbon so far. The article investigates four aspects which constrain the enforcement of an effective, coherent and efficient European Foreign Policy. This concerns a general erosion of Foreign Policy at first. Secondly, normative aims and pragmatic policies come into conflict and add up to a third challenge - the risk of provincialism. Finally, the article discusses what a pragmatic EU Foreign Policy could look like. The renunciation from the idea of European integration, however, is not inconceivable in this matter. The vulnerable Foreign Policy could turn out to be its first victim.

Barbara Lippert

\section{At the Margin: Export of Stability through further EU Enlargement}

The European Union has achieved a substantial contribution to building a new order in Europe after the fall of the Berlin wall. Its main instrument was the accession of new member states. By associating and finally the accession of the ten central eastern European countries, the EU extended the values and standards on which it is founded. Moreover, it benefited politically and economically from this export of stability. However, the conditions in the Eastern Neighbourhood for further enlargement as a foreign and security policy are difficult. Considering this, the article recommends a further development of the European Neighbourhood Policy and a prioritisation of deepening European integration. 
Daniel Göler

The Limits of the ,Cost-of-Non-Europe'-Narrative: Remarks on the Meaning of European Integration

After two world wars, elites could win European citizens support for the project of integration by presenting it as a contrast to war and tyranny. Due to the success of the peace-fostering effect of the EU, the relevance of this narrative has faded. In this context the 'cost- benefitnarrative' entered the political debates as a new narrative. Against the background of the current Euro and debt crisis, the article questions the appropriateness of the rationalist 'costbenefit-narrative'. It concludes that this narrative is hardly suitable to function as a new legitimisation of the integration process. Instead, it is argued that Europe needs a comprehensive debate about the meaning of the integration process. As 60 years ago, both, economic and ideational aspects have to play a decisive role in the process of giving meaning to European integration.

Timm Beichelt and Christina Ücker

\section{European Studies between Affirmation and EU-Criticism}

Considering the pluralism of academic approaches in European Studies it seems that their body of knowledge is essentially affected by European transformation processes. Moreover, debates on naming and the performance of the field of research reveal developments in science which imply a lot more than the departure from disciplinary knowledge organisation. The article outlines the nominal and conceptual development of European Studies. The research field is characterised by a distinction between European Studies as an area studies approach and EU Studies which bear a social science orientation. Within EU Studies, we can further distinguish between affirmative and critical EU Studies.

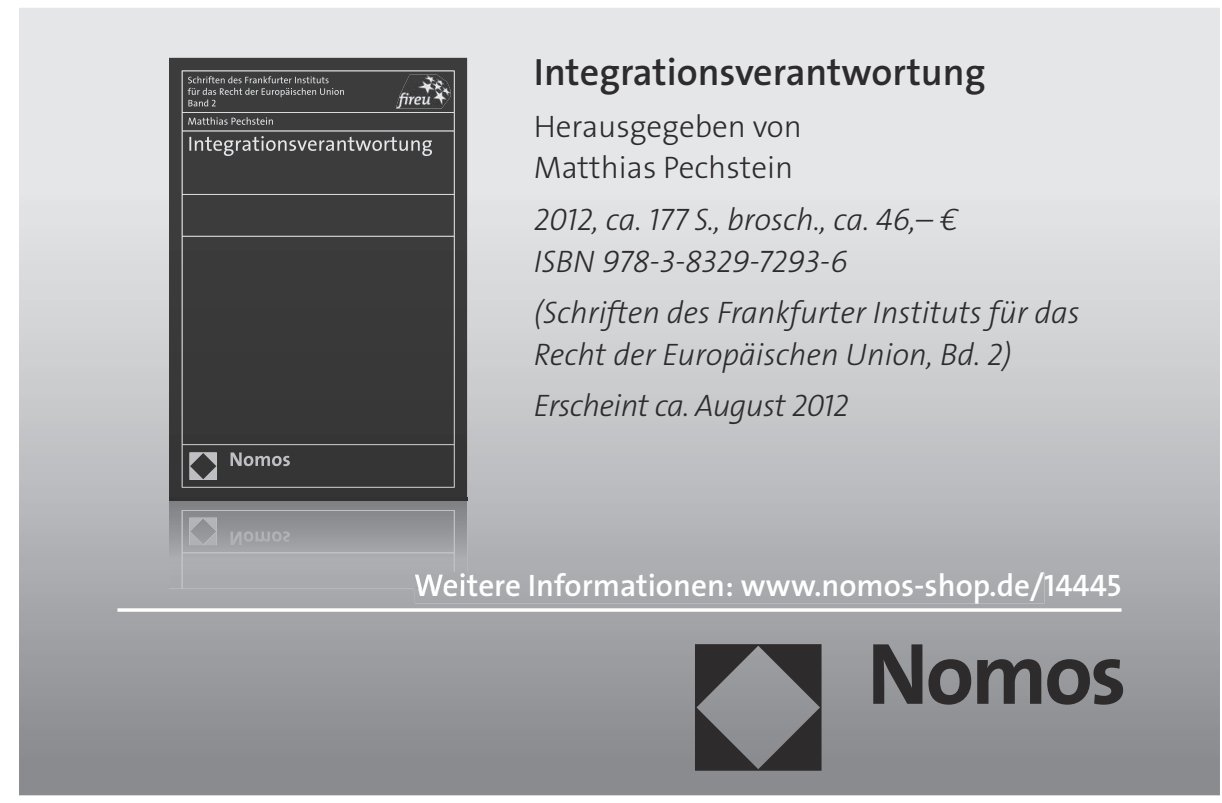

